\title{
THE IMPACT OF COMPETITION IN PHYSICAL ACTIVITY AND SPORT ON THE SELF-PERCEPTION OF INDIVIDUALS WITH PHYSICAL DISABILITIES
}

\author{
Michael Cocquyt, Erik Sigmund*
}

Faculty of Kinesiology and Rehabilitation Sciences, Catholic University of Leuven, Leuven, Belgium

* Faculty of Physical Culture, Palacký University, Olomouc, Czech Republic

Submitted in June, 2010

BACKGROUND: Physical activity has traditionally been treated as one of many strategies to improve an individual's quality of life. Until fairly recently, this presumption has been accepted as truth and little research has been done on proving or disproving the claim. Now, there has been a larger focus on it and numerous studies have analyzed the contribution physical activity has on the individual's quality of life in all areas.

OBJECTIVE: This study analyzes the current literature in the area of physical activity and sport as related to selfperception and the overall quality of life in individuals with physical disabilities.

METHODS: Using the websites of the following literature databases: Pubmed, Sport Discus, Medline, APAQ archives, and European Journal of Adapted Physical Activity archives, articles from 1990-2009 were selected based on their focus on analyzing the relationship of self-perception and quality of life to physical activity and sport for individuals with physical disabilities. Using these mentioned search programs, 274 articles were found using the keywords for this article. Of these, 40 articles were chosen for being applicable to the topic and target population. Nine of these articles were then used in the direct results as others were used for anecdotal or background information, due to their lack of consistent terminology. Without consistent terminology it was not possible to use these anecdotal articles to make proper comparisons of results. These trends, from the remaining nine articles were then compared to studies with able-bodied populations.

RESULTS: The authors found that, overall, there is a significant positive relationship between physical activity and sport programs on the one hand, and increased self-perception among individuals with physical disabilities on the other. This increase can be seen in the process of the comparison of the individual constructs of self-perception as well as of the differences in self-perception as a whole. Quality of life was also seen, in some studies, to be an additional reference for comparison. The inclusion of competition had no significant effect on these relationships of selfperception. However, individuals competing at an elite or world class level showed significantly higher self-perception than all other groups. When able-bodied studies were compared, similar trends were found in both overall difference in self-perception and differences seen between competition levels.

CONCLUSIONS: Findings show that competition should be included in physical activity and sport programs, for individuals with physical disabilities, only if it results in an increase in positive experiences for the participants. Participation in physical activity and sport programs contribute to an improvement in the quality of life of individuals with physical disabilities.

Keywords: Self-perception, quality of life, disability, competition, wheelchair, athletes.

\section{INTRODUCTION}

This study analyzes the current literature in the area of physical activity and sport in relationship to selfperception and the overall quality of life in individuals with physical disabilities (from 1990 till 2009). First of all, it is important to discuss the definition and implications of self-perception. Perception of self typically encompasses the constructs of self-concept, self-esteem and self-efficacy (Tenenbaum \& Eklund, 2007). Simply stated, self-perception is one's opinion of one's own personal identity. It is important to examine the com- ponents of self-perception so that we may have a deeper understanding of the term's overall meaning. All of these component terms are similar; however, they have important differences which separate them into their own distinctive roles of importance. At a minimum, a brief explanation is important to see their individual contributions to overall self-perception.

Self-concept is a multidimensional construct, in that it includes the cognitive, affective and behavioral domains. Self-concept comprises a number of descriptors that people compare themselves to. The overall selfconcept thus reflects the summation of an individual's 
self-evaluations of the set descriptors and these represent how good the person feels about himself or herself (Beck, Rush, Shaw, \& Emery, 1979).

Self-esteem defines how the individual "feels" about their "self" and how they value others' opinions of their personal "self" through the process of comparison. Selfesteem is commonly regarded as the evaluative component of self-conception and is thought to consist of the fundamental process of cognitive comparison and affect (Sonstroem, 1982). Although it is important to know the implications of others' opinions through study of self-esteem, this construct is commonly used inappropriately in place of self-perception. For the purposes of this study it is important to note this difference so that we have a full appreciation of an individual's perception.

Finally self-efficacy analyzes how the individual values or feels about their "self" in reference to their own past performance. This differs from self-concept and self-esteem, which involve external comparisons. Being the most intrinsically based construct self-efficacy is imperative in the understanding of an individual's perceptions of self. This is most important to note when discussing the causes of differences in self-perception and if reasoning is external or internal to the "self".

By combining these components into one term we are better able to gather an overall difference in idea of an individual's views and beliefs about themselves. At times these terms are used interchangeably or differently in the literature. So the definitions from the literature will be explained, throughout the review, in order to clarify any confusion. Due to its broad spectrum and ability to cover a wide range of emotions, an individual's self-perception is the most appropriate measure of finding how they view and judge their total self.

\section{RATIONALE AND AIM OF STUDY}

Taking this understanding of self-perception, it is now possible to analyze and compare how activities alter individuals' self-perceptions. The main focus of analysis for this review will be to discover any particular trends in the literature, in order to form a theory statement which is supported by the similarities or differences in the findings of the literature. These trends of interest include: the effect of sport participation on self-perception levels and subsequent differences in the quality of life, and the effect competition has on these trends in self-perception.

The act of competition in relation to sport can completely change the goals and outcomes of the activity, as well as the perceptions the individual has of that activity, others, and themselves. Fox's model of physical self worth considers perception as a motivation when a positive outcome occurs, however, when a negative outcome occurs it can have the reverse effect as well
(Tennenbaum \& Eklund, 2007). In competition based programs, individuals may be exposed to a negative outcome more frequently due to loss and defeat. It is unclear whether this will affect their overall change in personal self-perception or not. The hope is to include competition so that successful experiences will occur, increase proving self-perception, however, it is unknown if this relationship exists and it has been relatively neglected in research especially in the population of individuals with physical disabilities. To determine the importance of including competition in the pursuit of using sport and physical activity to increase self-perception, this article focuses on comparing the recent literature on the topic. Trends in the literature on self-perception of athletes and competition are then discussed and compared relative to literature on able-bodied populations. These trends are then used to suggest applications to program design and future research in the field.

\section{METHODS}

A systematic review was used to examine the literature. This process can be best defined as a deductive design because of its more analytical analysis of text and graphical representation of data than statistical analysis and exact comparison of raw data. Using the websites of literature databases Pubmed, Sport Discus, Medline, APAQ archives, and the European Journal of Adapted Physical Activity archives, articles from 1990-2009 were selected based on their focus on analyzing the relationship of self-perception and quality of life to physical activity and sport for individuals with physical disabilities. These mentioned search programs found 274 articles using the keywords for this article. Of these, 40 articles were chosen as being applicable to the topic and target population. Nine of these articles were then used in our direct results and others were used for anecdotal or background information. Articles were also analyzed which contribute information on inclusion and the level of competition, and applicable studies including able-bodied populations. The trend of differences in selfperception and relevance are then shown numerically and graphically through the use of numeric tables and visual charts as well as by means of detailed descriptions and discussion by the author. The research methods of the studies varied as they used different means to gather and quantify their information and are as follows.

1. Orthopedic disability and socioemotional functioning by Yagmurlu, M. F., Yagmurlu, B., and Yilmaz (2009) included self-concept ratings, from the PiersHarris self-concept scale, of 95 Turkish youth in school grades 5 to 12 (mean age of 15.44 years).

2. Influence of adapted sport on quality of life: perceptions of athletes with cerebral palsy by Groff, Lundberg, 
and Zabriskie (2009) involved surveying 73 international $\mathrm{CP}$ athletes for demographic data, athletic identity, and quality of life. The data was then analyzed through descriptive statistics.

3. Psychosocial impact of participation in the National veterans wheelchair games and winter clinic by Sporner et al. (2009) used a cross sectional design involving 132 individuals who had participated in the National veterans wheelchair games in varying ways or did not participate. Measurements were made through the WHO Quality of life - brief tool and the Rosenberg self-esteem test. Group comparisons were then made by dividing groups by demographic information and participation levels.

4. The body in persons with an amputation by Sousa, Corredeira, and Pereira (2009) followed a hermeneutic approach by comparing semi-structured interviews of fourteen individuals with amputations who were either involved or not involved in sport.

5. Physical activity and self-perceptions among Hong Kong Chinese with an acquired physical disability by Sit, Lau, and Vertinsky (2009) asked a sample of 66 Hong Kong Chinese adults to complete a battery of questionnaires about physical activity and self-perceptions.

6. Psychological well being in wheelchair sport participants and nonparticipants by Campbell and Jones (1994) used measurements of psychological well being which had already been tested for validity and reliability. Their 93 athlete participants and 23 nonathlete participants were measured in domains of mood, trait anxiety, self-esteem, mastery, and selfperceptions. Comparisons were then made between athletes and nonathletes and between the levels of competition.

7. Self-concept and need for achievement of men with physical disabilities by Super and Block (1992) measured self-concept and need for achievement scores for 45 men with physical disabilities and 50 men without disabilities. The results from the Tennessee self-concept scale counseling form and the thematic apperception test were then entered into analysis through ANOVA and ANCOVA processes.

8. Athletic identity and self-esteem in Flemish athletes with a disability by Van De Vliet, Van Biesen, and Vanlandewijck (2008) compared 23 Paralympic and 37 non-Paralympic elite athletes with each other and results from other related studies. Their comparisons were made through using the instruments of the athletic identity measurement scales, the Rosenberg self-esteem scale and the physical self-perception profile.

9. Athletic identity and sport orientation of adolescent swimmers with disabilities by Martin, Adams-Mushett, and Smith (1995) utilized the athletic identity measurement scale and sport orientation questionnaire to test relationships between athletic identity and sport orientation in 57 youth swimmers with disabilities.

\section{RESULTS}

The results will be discussed in three parts, aligned with the hypotheses of the study. Numerous studies, including those from Campbell and Jones (1994); Ferreira and Fox (2008); Groff, Lundberg, and Zabriskie (2009); Mazzoni, Purves, Southward, Rhodes, and Temple (2009); Sinnakaruppan, Macdonald, McCafferty, and Mattison, (2010); Sousa, Correderia, and Pereira (2009); Sherrill, (2004); Sporner et al. (2009), and Yagmurlu, M. F., Yagmurlu, B., and Yilmaz (2009) supported hypothesis one, there is a positive relationship between physical activity and sport and an individual's self-perception. Campbell and Jones (1994) clearly document this in their comparison between the self-perceptions of individuals with disabilities involved in sport and the control of (non participants) group $(\mathrm{F} / 11,108 /=4.14, \mathrm{p}<0.00001)$. This is observable in other relationships through higher levels of selfconcept (Yagmurlu, M. F., Yagmurlu, B., \& Yilmaz, 2009), and overall quality of life (Bogolijub, Mihajlovic, Zoran, Marijela, \& Ninoslav, 2001; Groff, Lundberg, \& Zabriskie, 2009; Sporner et al., 2009) in groups of individuals with disabilities, involved in physical activity and sport programs, as compared to those not involved. This trend can also be seen clearly in the interviews and discussions of Sousa, Corredeira, and Pereira's (2009) research including individuals with amputations who were either involved and not involved in physical activity and sport programs. One quotation from this article clearly shows the difference in how athletes feet more comfortable with their physical selves. Eva, a non athlete, said she "feels good" when her prosthesis is "unnoticed" and Carlos, a former professional soccer player who despite amputation remains very active, "feels good in shorts" when describing how he dresses for the gym. TABLE 1 (below) displays the most appropriate quantitative information from these studies. TABLE 1 shows these values to demonstrate the relationships found and their high significance.

As for hypothesis two, it was not confirmed that there will be no effect on this relationship (seen in hypothesis one) due to the level of competition within the physical activity or sport. Studies for this comparison used the Athletic Identity Measurement Scales as cited in other sources to be significantly correlated with quality of life more than any other factor including length of participation, age, gender, ethnicity, or severity of disability. Although there was no significant difference 
found between levels of competition overall, under further analysis there was a significant difference found when comparing recreational, regional, and national athletes with a physical disability, as a group, to international or elite athletes with a physical disability. This trend can also be seen in the Groff, Lundberg, and Zabriskie (2009) study which compared recreational athletes with disabilities to elite athletes with a physical disability (the elite athletes sample means are 48.6, 48 and for recreational athletes they are 39.16, 35.05) and Tasiemski, Kennedy, Gardner, and Blaikley (2004) who compared nonathletes, to regional, national, and international athletes with physical disabilities (their scores on a 1-7 scale were $2.0,2.8,3.1$, and 3.7 respectively).

Hypothesis three, there will be no confirmation of differences in these relationships (as seen in hypothesis one and two) between studies including individuals with physical disabilities or individuals without physical disabilities. When comparing the results of their studies to studies of individuals without physical disabilities, Super and Block (1992) found that there was no significant difference in trends of self-concept between individuals with or without physical disabilities as regards their involvement in physical activity and sport. They also found no significant difference in the scores of individual groups. As for comparing individuals with a disability who are not active, to individuals without disabilities who are not active, Groff, Lundberg, and Zabriskie (2009) also compared their findings with able-bodied studies. They also found the same trends to exist. These comparisons showed more variance due to comparing their results to others rather than collecting the data themselves; however the same trends are clearly seen in Fig. 1. When comparing their results at competition level to able-bodied studies Groff, Lundberg, and Zabriskie (2009) found slightly different values but a very similar trend between the two groups. Van De Vliet, Van Biesen, and Vanlandewijck (2008) used the athletic identity measurement scales on 60 elite Flemish athletes with disabilities. They then compared the results of the Paralympic and non-Paralympic elite athletes to the results of other studies involving the AIMS and populations of athletes with and without disabili- ties. They found theat results of their Paralympic athletes had results and AIMS scores identical to those of University football players in a study by Brewer (1993) (both scores $5.1 \pm 0.9$ in a range of 1-7), and their nonParalympic elite athletes had results just slightly below that $(4.8 \pm 1.2$ in a range of $1-7)$.

\section{DISCUSSION}

\section{Application of findings}

From the presented findings it is somewhat unclear as to what recommendations we can make to the coordinators of sport and physical education programs, in response to the inclusion or exclusion of competition or even what level of competition is appropriate in the goal of increasing self-perception in individuals with physical disabilities. It is very clear that physical activity and sport has a strong correlation to increased selfperception, and the more qualitative studies included in this review (Sousa, Correderia, \& Pereira, 2009; Sporner et al., 2009); suggest that there is a strong argument for causation as well. Despite this, no studies could give a clear answer through their results on the effect competition has on this trend. We know that elite athletes, in both populations with and without physical disabilities have significantly higher degree of self-perception, but why does this trend not occur in the transition from recreational to lower level competitive athletes? Perhaps the explanation is not in the results but rather in the question. The results as seen across studies (Campbell \& Jones, 1996; Groff, Lundberg, \& Zabriske, 2009; Sporner et al., 2009; Super \& Block, 1992; Yagmurlu, M. F., Yagmurlu, B., \& Yilmaz, 2009) are consistent, despite not being able to give a great deal of insight into the future planning of sport and physical education programs. Instead of looking at competition objectively (focusing on success or failure in winning or losing) maybe a more subjective approach (an individual's personal views and perceptions) would give us more applicable information for utilization in the field.

A study, by McAuley and Tammen (1989), examined the effects of competition from both the objective and

\section{TABLE 1}

Relationships of physical activity and sport and self-perception

\begin{tabular}{|l|l|c|c|}
\hline \multicolumn{2}{|l|}{ Study authors and design of comparison } & Value & P-value \\
\hline $\begin{array}{l}\text { Yagmurlu, M. F., Yagmurlu, B., } \\
\text { \& Yilmaz, (2009) }\end{array}$ & Physical activity and sport participation and self concept & $\mathrm{R}^{2}=2.5$ & $<.05$ \\
\hline Groff, Lundenburg, \& Zabriskie (2009) & Athletic identity and quality of life & $\mathrm{R}=0.505$ & $<0.001$ \\
\hline Sporner et al. (2009) & $\begin{array}{l}\text { Quality of life physical health value } \\
\text { (participants vs. non participants) }\end{array}$ & 14.2 vs. 13.0 & 0.095 \\
\hline Campbell \& Jones 1994 & $\begin{array}{l}\text { Self perceptions of health (top) and well being (bottom) } \\
\text { (participants vs. non participants) }\end{array}$ & $\begin{array}{c}6.65 \text { vs. } 4.83 \\
7.13 \text { vs. 5.76 }\end{array}$ & $<0.01$ \\
\hline
\end{tabular}


Fig. 1

Athletic identity scores - adapted from Groff, Lundenburg, and Zabriskie (2009)

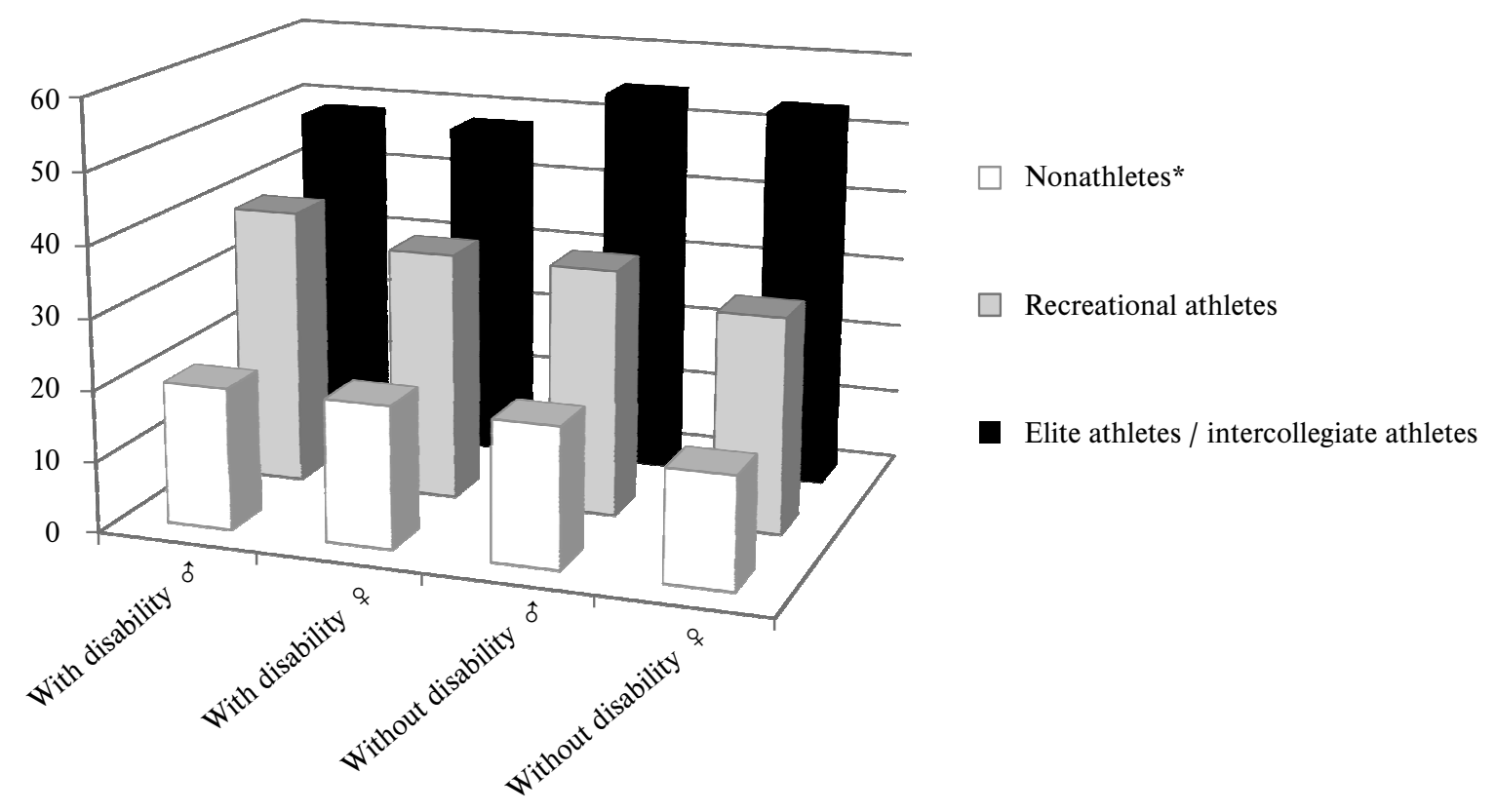

*Scores for nonathletes with disabilities from Tasiemski, Kennedy, Gardner, and Blaikley (2004).

subjective viewpoints. This more qualitative approach allowed success to be measured both in winning and losing as well as from the individuals' perceptions of their success or failure. As discussed earlier (see background information) the perception of winning and losing may have nothing to do with the physical outcome of competition against an opponent. Cognitive evaluation theory suggests that an individual's perception of competitive situations can affect their intrinsic motivation. By utilizing a multidimensional measure of intrinsic motivation during a "one-on-one" basketball jump-shooting competition the authors were able to better see how an individual's self-perception correlated with their actual success. "The results indicated that both winners and highly successful individuals displayed significantly greater intrinsic motivation..." Once multivariate analyses of variance were completed on the results, significant differences were found only between the groups perceived to be successful. These highly successful individuals perceived themselves as trying harder, being more competent, and enjoying the activity more. So despite competition being the cause of winning and success for these individuals, their perception of the activity and their involvement was more important to an increased level of self-perception than the simple inclusion or exclusion of competition alone.

Another study by Gimeno and García-Mas (2008) agreed with this idea of successful experiences rather than simply competition inclusion or exclusion, however their goal was more focused on motivation and how to increase motivation through improved self-perception. The authors of this study felt that "the PE teacher should encourage students to feel satisfaction in the practice of sport through the perception of competition in a self-referencing way". As discussed earlier in the theories of self-concept (Bandura, 1997), improved self-perception caused by increased positive experiences can motivate the individual as well. This relationship of success and motivation was further analyzed by comparing high and low EGO individuals as compared to high and low competition settings. It was found that individuals with bigger EGOs, who were placed in a position to perform higher competitive tasks, were more successful and more motivated. The same was found for individuals with smaller EGOs in competitive tasks at a lower level (Gimeno \& Garcia-Mas, 2008). From this study it is clear that it is more important to match the task to individuals when deciding to include or exclude competition if we are to create a positive and successful environment which improves self-perception and motivation. By choosing appropriate activities, making adaptations, and organizing the environment for success, teachers can influence in meaningful ways the self-perception of individuals who have movement difficulties.

The results of the study by Martin, Adams-Mushett, and Smith (1995) on youth swimmers with disabilities support this philosophy. They found athletes with strong athletic identities and the desire to achieve, having expressed that desire through self referenced and normative goals. Therefore they recommend coaches should 
acknowledge these athletes and continue to provide them challenging opportunities for athletic excellence.

Although the studies from McAuley and Tammen (1989), Gimeno and Garcia-Mas (2008) included college aged men and women without physical disabilities, by combining them with the results of related studies we can see evidence supporting the theories of competition and self-perception which create the framework of this thesis. It is not appropriate to take these results and apply them automatically to the population of individuals with physical disabilities however; future research regarding self-perception and competition should take these results into account during study design.

As to other points for future study, if we want to make true qualitative analyses of our participants, future studies should assess more of the personality and mindset of the individuals as well as the competitive structure of the activities we involve them in. By measuring the competitive nature of the individuals (perhaps via a test like the sport orientation questionnaire as used in Martin, Adams-Mushett, \& Smith, 1995) as well as the competitive nature of the activity, further analysis could be done to ensure the importance of aligning competitive structures with the goal of increasing the level of self-perception in individuals with physical disabilities.

\section{Limitations of study and recommendations for future studies}

In this study, the main limitation was the combining of results from a variety of studies. Although it was not the purpose of this study to create definitive findings but rather theory for future studies to be based on, the variety of studies used with their variety of measurements, at times, made comparisons more difficult to fully understand. Also, through this analysis, the competitive level was assessed and not competition inclusion or exclusion. It is difficult to know exactly what measures of competition studies participants used, so the competitive level was a more consistent and reliable measurement. Once again it was not the purpose to create definitive findings but rather look at this theory based on the findings. A further study using a more specific quantitative approach is now the next appropriate step to further support the findings of this paper. Through this more specific quantitative process, even more definitive claims on the application of the recommendations of this study will be possible.

Any future study should also take into account the sex of the individual or, more appropriately, their sex role type. A study by Hall, Durborow, and Progen (1986) separated female athletes into four sex role types. Their results supported the results of this paper in that athletes had an overall greater self-esteem than nonathletes. They also found nonathletic females in the feminine role type had the lowest self-esteem of all groups. Although this study is not applicable to the findings of this study, by focusing on the self-esteem of able-bodied individuals, its findings are important to suggesting comparing males and females differently. All of the studies included had minimal differences in scores between men and women; however, examining sex role types could be important to individualizing studies and creating more subjective outcomes.

\section{CONCLUSION}

In the overall results it can be seen that there is a clear positive trend in the relationship between physical activity and sport programs and increased self-perception, in individuals with physical disabilities.

Competition level overall did not have a significant effect on the trend of physical activity and sport and increased self-perception in individuals with physical disabilities. However, competitors at the elite level (Paralympic and international athletes) showed a significantly higher level of self-perception than other levels of competition and recreational athletes.

Although it is still unclear if individuals with physical disabilities have significantly lower levels of self-perception than individuals without disabilities, the trends of relationships between physical activity and sport programs and a higher level of self-perception and the relationships previously stated in response to being at competition level are very similar in both populations. Therefore, the findings of this study may be applicable to the population of individuals without disabilities as well.

In closing, these findings show that competition should be included in physical activity and sport programs for individuals with physical disabilities only if it results in an increase in positive experiences for the participants.

\section{ACKNOWLEDGMENT}

The study has been supported by the research grant from the Ministry of Education, Youth and Sports of the Czech Republic (No. MSM 6198959221) "Physical Activity and Inactivity of the Inhabitants of the Czech Republic in the Context of Behavioral Changes”. 


\section{REFERENCES}

Beck, A. T., Rush, A. M., Shaw, B. F., \& Emery, G. (1979). Cognitive therapy of depression. New York, NY: The Guilford Press.

Bandura, A. (1997). Self-efficacy: The exercise of control. New York: Freeman.

Bogolijub, B., Mihajlovic, D. J., Zoran R. P., Marije1a, M. P., \& Ninoslav, R. (2001). Is self-perception of health the most important factor contributing to improvement of quality of life in high risk coronary patients after the operation? Quality of Life Research, $10(3), 252-255$.

Campbell, E., \& Jones, G. (1994). Psychological well being in wheelchair sport participants and nonparticipants. Adapted Physical Activity Quarterly, 11, 404-415.

Ferreira, J. P., \& Fox, K. R. (2008). Physical self-perceptions and self-esteem in male basketball players with and without disability: A preliminary analysis using the physical self-perception profile. European Journal of Adapted Physical Activity, 1(1), 35-49.

Gimeno, F., \& García-Mas, A. (2008). Motivation in the teaching of physical education according to the achievement goal theory: Methodological considerations. Quality \& Quantity, 44(3), 583-593.

Groff, D. G., Lundberg, N. R., \& Zabriskie, R. B. (2009). Influence of adapted sport on quality of life: Perceptions of athletes with cerebral palsy. Disability \& Rehabilitation, 31(4), 318-326.

Hall, E. G., Durborow, B., \& Progen, J. L. (1986). Selfesteem of female athletes and non athletes relative to sex role type and sport type. Sex Roles, 15(7/8), 379-390.

Martin, J. J., Adams-Mushett, C., \& Smith, K. L. (1995). Athletic identity and sport orientation of adolescent swimmers with disabilities. Adapted Physical Activity Quarterly, 12, 113-123.

Mazzoni, E. R., Purves, P. L., Southward, J., Rhodes, R. E., \& Temple, V. A. (2009). Effect of indoor wall climbing on self-efficacy and self-perceptions of children with special needs. Adapted Physical Activity Quarterly, 26, 259-273.

McAuley, E., \& Tammen, V. V. (1989). The effects of subjective and objective competitive outcomes on intrinsic motivation. Journal of Sport and Exercise Psychology, 11(1), 84-93.

Sinnakaruppan, I., Macdonald, K., McCafferty, A., \& Mattison, P. (2010). An exploration of the relationship between perception of control, physical disability, optimism, self-efficacy and hopelessness in multiple sclerosis. International Journal of Rehabilitation Research, 33(1), 26-33.

Sherrill, C. (2004). Adapted physical activity, recreation, and sport: Crossdisciplinary and lifespan (6th ed.). New York: McGraw-Hill Publishers.
Sit, C. H. P., Lau, C. H. L., \& Vertinsky, P. (2009). Physical activity and self-perceptions among Hong Kong Chinese with an acquired physical disability. Adapted Physical Activity Quarterly, 26, 321-335.

Sonstroem, R. J. (1982). Exercise and self-esteem: Recommendations for expository research. Quest, 33(2), 124-139.

Sousa, A. I., Corredeira, R., \& Pereira, A. L. (2009). The body in persons with an amputation. Adapted Physical Activity Quarterly, 26, 236-258.

Sporner, M. L., Fitzgerald, S. G., Dicianno, B. E., Collins, D., Teodorski, E., Pasquina, P. F., \& Cooper, R. A. (2009). Psychosocial impact of participation in the national veterans wheelchair games and winter sports clinic. Disability \& Rehabilitation, 3l(5), 410-418.

Super, J. T., \& Block, J. R. (1992). Self-concept and need for achievement of men with physical disabilities. The Journal of General Psychology, 119(1), 73-80.

Tasiemski, T., Kennedy, P., Gardner, B. P., \& Blaikley, R. A. (2004). Athletic identity and sports participation in people with spinal cord injury. Adapted Physical Activity Quarterly, 21, 364-378.

Tenenbaum, G., \& Eklund, R. C. (2007). Handbook of sport psychology. New Jersey: John Wiley \& Sons Inc.

Van De Vliet, P., Van Biesen, D., \& Vanlandewijck, Y. C. (2008). Athletic identity and self-esteem in Flemish athletes with a disability. European Journal of Adapted Physical Activity, 1, 9-21.

Yagmurlu, M. F., Yagmurlu, B., \& Yilmaz, M. (2009). Orthopedic disability and socioemotional functioning. Pediatrics International, 51(5), 637-644.

\section{VLIV SOUTĚŽENÍ PŘI POHYBOVÉ AKTIVITĚ A SPORTU NA SEBEHODNOCENÍ JEDINCŮ S TĚLESNÝM POSTIŽENÍM}

(Souhrn anglického textu)

VÝCHODISKA: Zapojení do pohybové aktivity je jednou z tradičních strategií ke zlepšení kvality lidského života. Aplikování této strategie je již hodně publikačně doloženo. Proto bude př́spěvek pohybové aktivity ke kvalitě života, sebevnímaní a sebehodnocení obsahem předložené práce.

CíL: Cílem studie bylo analyzovat současné publikace hodnotící vliv účasti ve sportu a organizované pohybové aktivitě na sebehodnocení a kvalitu života jedinců s tělesným postižením.

METODIKA: Literární zdroje byly vyhledávány prostřednictvím informačních databází Pubmed, Sport Discus, Medline, APAQ archives a European Journal of Adapted Physical Activity archives z let 1990-2009 a vybírány podle zaměření na analýzu vztahů mezi sebehodnocením, kvalitou života a pohybovou aktivitou a spor- 
tem u jedinců s tělesným postižením. Vyhledávání podle stanovených klíčových slov odhalilo 274 článků. Celkem $40 \mathrm{z}$ nich obsahovalo úplné a validní informace $\mathrm{k}$ požadované analýze. Pro komparační analýzu výsledků bylo použito $9 \mathrm{z}$ nich. Články byly rozděleny a diskutovány podle ověřovaných hypotéz. Při zjištování trendů byly akceptovány a zviditelněny kulturní odlišnosti. Zjištěné trendy byly srovnávány s výsledky obdobně zaměřených studií u jedinců bez pohybových omezení.

VÝSLEDKY: Např́ič srovnávanými výsledky diskutovaných článků byl potvrzen pozitivní vztah mezi pohybovou aktivitou, účastí ve sportu a vyšším sebehodnocením. Zjištěny však byly kulturní odlišnosti v sebehodnocení tělesně postižených jedinců. V západních zemích byl zjištěn výrazně pozitivní vztah mezi pohybovou aktivitou, účastí ve sportu a vyšším sebehodnocením jedinců s tělesným postižením. Avšak ve východních zemích není tento vztah jednoznačně pozitivní. Nejednoznačnost vztahu v pracích $\mathrm{z}$,východních“ zemí lze vysvětlit obecně nižším sebehodnocením jedinců s tělesným postižením oproti vyspělým západním zemím s vyšší kulturní diverzitou. Fenomén soutěžení a soupeření v pohybové aktivitě a sportu nemá výrazný vliv na sebehodnocení jedinců s tělesným postižením. Pouze sportovci s tělesným postižením na vrcholové úrovni vykazují výrazně vyšší sebehodnocení než ostatní skupiny stejně postižených jedinců. Stejné trendy byly zjištěny $\mathrm{u}$ jedinců bez tělesného postižení ve studiích $\mathrm{z}$ vyspělých západních zemí.

ZÁVĚRY: Z výsledků je patrné, že pohybovou aktivitou a zapojením do sportovních programů lze zvýšit sebehodnocení jedinců se specifickými pohybovými potřebami a přsispět k jejich vyšší kvalitě života. Při tvorbě pohybových programů pro jedince s tělesným postižením je však nutné zohledňovat kulturní specifika. Výsledky studií potvrzují teorii úspěšnosti v životě sportovců s tělesným postižením a skutečnost, že pohybové programy mohou propojit soutěžní a dovednostní úroveň jedinců.

Klíčová slova: sebehodnocení, kvalita života, tělesné postižení, soutěžení, vozíčkár, sportovec.

\section{Michael Cocquyt M.S.}

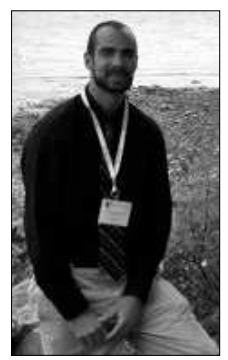

12 Tallwood Dr. Hilton

14468 New York

United States of America

\section{Education and previous work experience}

Graduated from the College at Brockport State University of New York with a Bachelors of Science in Physical Education in 2009. Then completed Masters in Adapted Physical Activity through the Erasmus Mundus Masters Program in Adapted Physical Activity through the Universities of K. U. Leuven in Leuven, Belgium and Palacký University in Olomouc, Czech Republic in 2010. Currently work in the field as a preschool teacher while travelling the United States directing sport, recreation and environmental education camps for youth with and without disabilities. 